\title{
Estimation of Tobacco Leaf Area by a Non-destructive Method
}

\author{
Onássis Deivis Schlösser ${ }^{1}$, Emilso Damm Dos Santos ${ }^{1}$, Tainan Vechietti ${ }^{1}$, Rodrigo Ivaniski Della Flora ${ }^{1}$, \\ Felipe Tascheto Bolzan ${ }^{2} \&$ Ivan Carlos Maldaner $^{1}$ \\ ${ }^{1}$ Farroupilha Federal Institute, São Vicente do Sul, Brazil \\ ${ }^{2}$ Federal University of Santa Maria, Santa Maria, Brazil \\ Correspondence: Onássis Deivis Schlösser, Farroupilha Federal Institute, Rua Augusta, no 41, Bairro Camobi, \\ CEP: 97105-115, Santa Maria, RS, Brazil. Tel: 55-55-999-434-711. E-mail: onassis322013@gmail.com
}

Received: October 8, 2020

Accepted: November 4, 2020

Online Published: November 15, 2020

doi:10.5539/jas.v12n12p170

URL: https://doi.org/10.5539/jas.v12n12p170

\begin{abstract}
The leaf area index (AFI) is an important variable when evaluating the growth, development and possible productivity of a crop. The objective of this article was to determine mathematical models that allow estimating the leaf area of tobacco from measurements of dimensions of length and width of tobacco leaves. The experimental design used was in blocks with four replications and two planting times. The treatments consisted of five commercial cultivars of Virginia type tobacco and Burley type. Of which the leaves were detached from the stem, and these leaves were fractionated in limbo and petiole. Its leaves were 10 models were obtained to estimate the leaf area of tobacco. All the models presented a significant test to estimate the leaf area. The power and quadratic models presented values of determination coefficients higher than linear models. It had the best results with the nonlinear power and quadratic model, using the squared width multiplied by length. Therefore, the measurements of the leaf area of tobacco can be estimated from potential, linear and quadratic equations with good precision. The models that use linear squared width measurements multiplied by leaf limbo length satisfactorily estimate the leaf area of tobacco.
\end{abstract}

Keywords: mathematical model, phenometric measurements, Virginia, Burley

\section{Introduction}

Tobacco (Nicotiana tabacum L.) is a plant belonging to the family Solanaceae, with erect size, shallow root, cylindrical stem and large leaves, oval, with central ribs and arranged in a helical way (Guerrero, 1995). Tobacco production is one of the leading agro-industrial activities in southern Brazil. With 574 producing municipalities and 144,000 registered producers in southern Brazil (SINDITABACO, 2017).

The economic importance of tobacco occurs from the use of its leaves to make its derivatives, such as cigarettes and cigars. Where, according to Peixoto et al. (2011) it becomes essential to know the leaf area of crops in the evaluation of plant growth and development, because it is linked to the increase in dry matter, in which it allows estimating the intensity of transpiration, net assimilatory rate, leaf area ratio, specific leaf area, and leaf area index.

The leaf area index (AFI) is an important variable when evaluating the growth, development and possible productivity of a crop (Taiz \& Zeiger, 2013) besides presenting regarding water need for irrigation purposes (Posse et al., 2009; Busato et al., 2010; Coelho Filho et al., 2012).

The yield is the result of the interaction of several biotic and abiotic factors, one of which is the interception of luminous energy and its transformation into chemical energy (Favarin et al., 2002); therefore, the leaf surface is determinant of the productive potential of a crop. In turn, the interception of solar radiation is directly dependent on leaf area index (Favarin et al., 2002), obtained by the ratio between the leaf area and the horizontal area of soil occupied by it.

The measurement of the leaf area can be done indirectly, non-destructively, and directly, destructively (Candido et al., 2013; Schmildt et al., 2014; Silva et al., 2015). To determine the leaf area directly, in general, all leaf structures of the plant are collected, characterizing the method as destructive, through which one has the need for high labor (Toebe et al., 2012), this besides destructing the leaves, may compromise the normal development of the plant, causing difficulties in monitoring the development of the crop cycle in the field (Malagi et al., 2010). 
In comparison, indirect and non-destructive methods allow successive evaluations in the same plant, in addition to speed evaluations (Toebe et al., 2012), in turn as they are not characterized as destructive, as they can provide accurate estimates of PA from the beginning until the end of the cycle following the same plant (Peksen, 2007).

For tobacco culture, so far, no models have been found to estimate the leaf area of culture by a non-destructive method. Through these models, it is possible to estimate the leaf area of tobacco and the estimation of possible damage by hail and pests. For this purpose, the objective of this study was to determine mathematical models that allow estimating the leaf area of tobacco from measurements of dimensions of length and width of tobacco leaves.

\section{Method}

The experiment was conducted in the field in the agricultural year in 2017, in an experimental area of the Federal Farroupilha Institute-São Vicente do Sul Campus, located in the Central Depression of the State of Rio Grande do Sul (Latitude: $29^{\circ} 41^{\prime} 30^{\prime \prime} \mathrm{S}$; Longitude: $54^{\circ} 40^{\prime} 46^{\prime \prime} \mathrm{W}$, Altitude: $129 \mathrm{~m}$ ). The climate of the region, according to the Classification of Köppen, is of the fundamental type $\mathrm{Cfa}$, characterized as humid subtropical, without defined dry season, with hot summers (Heldwein et al., 2009). The soil of the site is classified as Dystrophic Hard-setting Gray-Brown Argisol (EMBRAPA, 2006), presenting a superficial horizon Ap, with the transition to horizon B textural about $0.3 \mathrm{~m}$ depth.

The production of tobacco seedlings was carried out in a float system, in a low tunnel greenhouse species, until it was around $12 \mathrm{~cm}$ in height of aerial part, presenting 4-5 leaves. The seedlings were transplanted into the cultivation area, on September 6 and October 3, 2017, in a conventional soil tillage system, in chameleons consisting of $0.3 \mathrm{~m}$ high, $2.7 \mathrm{~m}$ in length and $1.20 \mathrm{~m}$ of spacing between them. Fertilization was performed according to soil chemical analysis, following the technical recommendations of tobacco crops (SBCS, 2016).

The experimental design used was in randomized blocks with four replications and two planting times. The experimental area totaled $194.4 \mathrm{~m}^{2}$ in which the experimental units consisted of plots of $2.7 \times 3.6 \mathrm{~m}$ totalizing an area of $9.72 \mathrm{~m}^{2}$ each, consisting of three lines spaced in $1.20 \mathrm{~m}$ and 0.45 between plants. The population used was 18,518 plants per ha ${ }^{-1}$.

The treatments consisted of five commercial tobacco cultivars: CSC 439, CSC 497, CSC 4703, CSC 2305, and CSC 2101. The first three cultivars are Virginia type and the last two of the Burley type. These types of tobacco present similar development and management, distinguishing mainly in the harvest stage, when around four harvests are carried out in Virginia type cultivars and only one or two in Burley type cultivars.

To determine the leaf area of tobacco, the leaves were collected in the phenological stages 32 (vegetative stage with 32 leaves) and R2 (Full flowering), removing them a single plant at random from the experimental unit. The leaves were detached from the stem and counted separately from each collected plant. Each leaf was fractionated in limbo and petiole. The leaf limb area was determined by the indirect method using the ImageJ software.

Image $\mathbf{J}$ is a widely-used open source image analysis software that works on multiple platforms, developed by Wayne Rasband at the National Institute of Mental Health, USA, in Java language. With this application you can view, edit, analyze, process, save, and print 8,16 , and 32-bit images. Allows the processing of various image formats such as TIFF, GIF, JPEG, BMP, DICOM, and FITS. It supports the imaging technique, that is, a series of images that share a single window for animations. The window containing the results (area, perimeter, orientation, among others) allows them to be exported to a file, such as in XLS (Microsoft Excel) format. In ImageJ, the calculation of the areas is done by counting pixels from the regions selected by the user or by a specific algorithm (Rasband, 2011; Hannicke et al, 2012).

In order to make it possible to use the software, the measurements of length $(\mathrm{C})$ and width (L) of the leaf limbo of photosynthetically active and undamaged sheets were taken. The length was measured along the main rib and the width, perpendicularly, to the insertion of the petiole in limbo, always being measured in the wider section of the sheet. Stages V32 and R2 occurred, respectively, at 63 and 103 DAP (days after planting) in the second time at 75 and 94 DAP (days after planting).

For the use of the leaf dimension method, initially, the linear regression coefficients between PA and product $\mathrm{C} \times$ $\mathrm{L}$ were determined for each variable used. A sample composed of 700 tobacco leaves, called the "primary sample", were measured in the laboratory, with the standard ruler, thus determining the $\mathrm{C}$ and $\mathrm{L}$ of each sample sheet and then the PA of each sheet with the aid of the ImageJ software was determined to obtaining the leaf area.

In the laboratory, the "main sample" was first analyzed to obtain the mathematical equations, following the following sequence: measurement of leaf dimensions with the standard ruler, then the determination of PA was 
performed by the digital imaging method. The digital imaging method consisted of capturing leaf images positioned against a white background, through a digital camera, Sony ${ }^{\circledR}$ and model DSC-H20. To calculate AF in digital images, the scale and resolution at which the photograph was obtained should be based. In addition, the program is required that calculates the area of each element that composes the image (pixel) and allows its classification by dividing the image into classes: sheet and non-sheet. It is also important that the tool integrates the elements that belong to the same category and thus calculates the area of interest.

Thus, regression analyses were performed between the linear dimensions as a function of the product of length and width $(\mathrm{CL})$, the squared length multiplied by width $\left(\mathrm{C}^{2} \mathrm{~L}\right)$ and the square width multiplied by length $\left(\mathrm{L}^{2} \mathrm{C}\right)$. Linear, quadratic, potential models were adjusted. The Excel software, Version 2016® (Microsoft Corporation, 2016) was used to adjust the regression equations. The coefficients of the equations tested the statistical significance of $p>0.05$. The leaf area estimated by the mathematical model was compared with the leaf area measured utilizing data dispersion analysis around line 1:1, aiming to choose the best model.

The analyses for calibration of the model were performed using a different sample from the first one where the mathematical models were established, called "second sample", located in the same cultivation environment as the previous one, during the $2017 / 2018$ crop. The leaves were collected following the same method used to obtain the "primacy sample". However, this sample was used for the precision test of the equations, containing 840 images as a sample.

The choice of models was made among the equations that presented determination coefficient values $\left(\mathrm{R}^{2}\right)$ greater than 0.90. For the evaluation of the performance of the models, the statistic used was the square root of the average square of the error (RQME) calculated by (Janssen \& Heuberger, 1995; Maldaner, 2009):

$$
\mathrm{RQME}=\left[\frac{\sum_{\mathrm{i}=1}^{\mathrm{n}}(\mathrm{Si}-\mathrm{Oi})^{2}}{\mathrm{~N}}\right]^{0.5}
$$

where, "S" is the estimated value, "O" is the observed value and $\mathrm{N}$ is the number of observations. For the generation of the models, $\mathrm{N}$ is equal to 840 tobacco leaves to determine the equations and for the test of the equations; the $\mathrm{N}$ equal to 700 leaves was used.

The final model selected was based on the combination of higher $\mathrm{R}^{2}$ and the RQME values closer to zero, aiming to select by criteria of greater relationship and less error between the observed and estimated values.

\section{Result and Discussion}

Ten models were obtained to estimate the leaf area of tobacco, which of these 9 presented high coefficients of determination $\left(\mathrm{R}^{2}>0.90\right)$, and a model was generated for practical purposes, using only the width, with the Coefficient $\mathrm{R}^{2}$ of 0.848 . Regressions relating the mediated leaf area of tobacco plants with the equations obtained through linear measurements $\left(\mathrm{CL}, \mathrm{C}^{2} \mathrm{~L}\right.$, and $\left.\mathrm{L}^{2} \mathrm{C}\right)$ of the leaves showed that there was a correlation for these variables. The equations obtained allow satisfactory estimation of the leaf area of tobacco through linear equations, potency, and quadratic equations, as shown in Figure 1. 

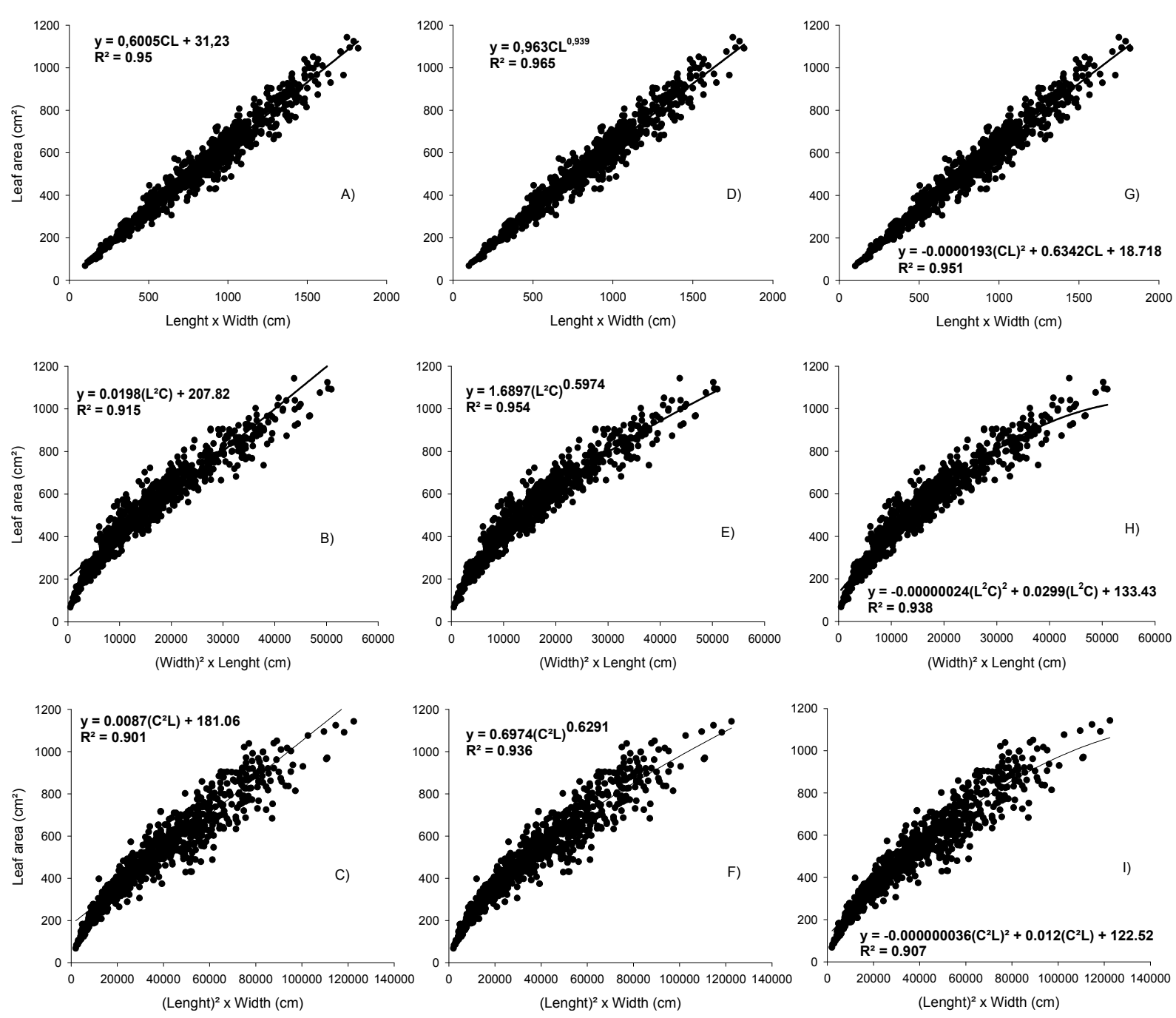

Figure 1. Regressions between leaf area of tobacco and linear measurements, using linear mathematical models

$(\mathrm{A}, \mathrm{B}, \mathrm{C})$, power $(\mathrm{D}, \mathrm{E}, \mathrm{F})$, and quadratic $(\mathrm{G}, \mathrm{H}, \mathrm{I})$

As a rule, linear type equations obtained $\mathrm{R}^{2}$ values lower than those of the potential type. Such result already been observed by several authors for cultures like cacao (Schmildt et al., 2017), canola (Tartaglia et al., 2016), mango (Lima et al., 2012) and manioc (Guimaães et al., 2019).

All the models presented a significant test $(\mathrm{p}<0.05)$ to estimate PA according to table 1 . The leaf area of tobacco is more accurately estimated by the models that use as a variable the square width multiplied by the length of the leaves $\left(\mathrm{L}^{2} \mathrm{C}\right)$ when compared to the models.

The power and quadratic models presented $\mathrm{R}^{2}$ coefficient values higher than linear models. The best results were obtained with the nonlinear power and quadratic model, using the square width multiplied by length $\left(\mathrm{L}^{2} \mathrm{C}\right)$, did not present the highest $\mathrm{R}^{2}$ in the generation of the model, but obtained the best performances in the test, with a lower RQME value and an angular coefficient of the test closest to one, in relation to linear models. Hinnah et al. (2014) obtained similar results for eggplant, but with the use of the product of length by width. Maldaner et al. (2009), in estimating the leaf area of sunflower, also obtained the best results with these equations, demonstrating their usefulness for this purpose.

Among the 10 models, the MSMS ranged from 61.81 to $126.43 \mathrm{~cm}^{2}$. The best results were obtained with quadratic (9) and power (5) models using square width multiplied by length $\left(\mathrm{L}^{2} \mathrm{C}\right)$, with RQME of $61,811 \mathrm{~cm}^{2}$ and $65.391 \mathrm{~cm}^{2}$, respectively, and $\mathrm{R}^{2}$ equal to 0.954 and 0.938 (Table 1). These also presented an angled coefficient of the test closest to one. 
Table 1. Models for estimating the leaf area $\left(\mathrm{cm}^{2}\right)$ of tobacco and their respective coefficients of determination $\left(\mathrm{R}^{2}\right)$ of model generation, linear coefficient (a), angular $(\mathrm{b})$, determination $\left(\mathrm{R}^{2}\right)$ of the model test, square root of the average square of error (RQME), as a function of width (L), length (C), its product (CL), square length multiplied by width $\left(\mathrm{C}^{2} \mathrm{~L}\right)$ and square width multiplied by length $\left(\mathrm{L}^{2} \mathrm{C}\right)$

\begin{tabular}{lllllll}
\hline \multirow{2}{*}{$\mathrm{N}^{\mathrm{j}}$} & Model & \multirow{2}{*}{$\mathrm{R}^{2}$} & \multicolumn{3}{c}{ Model test } \\
\cline { 3 - 7 } & & & $\mathrm{a}$ & $\mathrm{b}$ & $\mathrm{R}^{2}$ & $\mathrm{RQME}$ \\
\hline 1 & $\mathrm{AF}=0.600 \cdot \mathrm{CL}+31.23$ & 0.950 & 27.907 & 0.8931 & 0.968 & 71.304 \\
2 & $\mathrm{AF}=0.0198 \cdot\left(\mathrm{L}^{2} \mathrm{C}\right)+207.82$ & 0.915 & -2.278 & 0.9976 & 0.917 & 87.97 \\
3 & $\mathrm{AF}=0.0087 \cdot\left(\mathrm{C}^{2} \mathrm{~L}\right)+181.06$ & 0.901 & 39.553 & 0.8473 & 0.923 & 101.46 \\
4 & $\mathrm{AF}=0.963 \cdot \mathrm{CL}^{0.939}$ & 0.965 & 28.972 & 0.8861 & 0.969 & 73.677 \\
5 & $\mathrm{AF}=1.6897 \cdot\left(\mathrm{L}^{2} \mathrm{C}\right)^{0.5974}$ & 0.954 & 27.942 & 0.9209 & 0.959 & 65.391 \\
6 & $\mathrm{AF}=0.6974 \cdot\left(\mathrm{C}^{2} \mathrm{~L}\right)^{0.6291}$ & 0.936 & 50.830 & 0.8093 & 0.954 & 107.64 \\
7 & $\mathrm{AF}=6.8736 \cdot \mathrm{L}^{1.4944}$ & 0.848 & 76.324 & 0.8735 & 0.894 & 90.402 \\
8 & $\mathrm{AF}=-0.0000193 \cdot(\mathrm{CL})^{2}+0.6342 \cdot \mathrm{CL}+18.718$ & 0.951 & 32.413 & 0.8823 & 0.969 & 73.427 \\
9 & $\mathrm{AF}=-0.00000024 \cdot\left(\mathrm{L}^{2} \mathrm{C}\right)^{2}+0.0299 \cdot \mathrm{L}^{2} \mathrm{C}+133.43$ & 0.938 & 31.791 & 0.9532 & 0.955 & 61.811 \\
10 & $\mathrm{AF}=-0.00000024 \cdot\left(\mathrm{L}^{2} \mathrm{C}\right)^{2}+0.0299 \cdot \mathrm{L}^{2} \mathrm{C}+133.43$ & 0.907 & 79.079 & 0.7466 & 0.950 & 126.43 \\
\hline
\end{tabular}

The digital imaging method allowed excellent PA measurements, as can be observed by the proximity of the points to the 1:1 (Figure 2). Figures $2 \mathrm{~b}$ and $2 \mathrm{c}$ demonstrate that the two best models (9 and 5) estimation result in excellent adjustment with the growth of the leaf area, slightly distancing themselves from the trend line (1:1) to larger sheets while maintaining the accuracy of the Estimate. Figure 2a shows a good adjustment of equation 1, which uses the product dimensions of the length and width of the sheet, but a little further distance from the trend line.
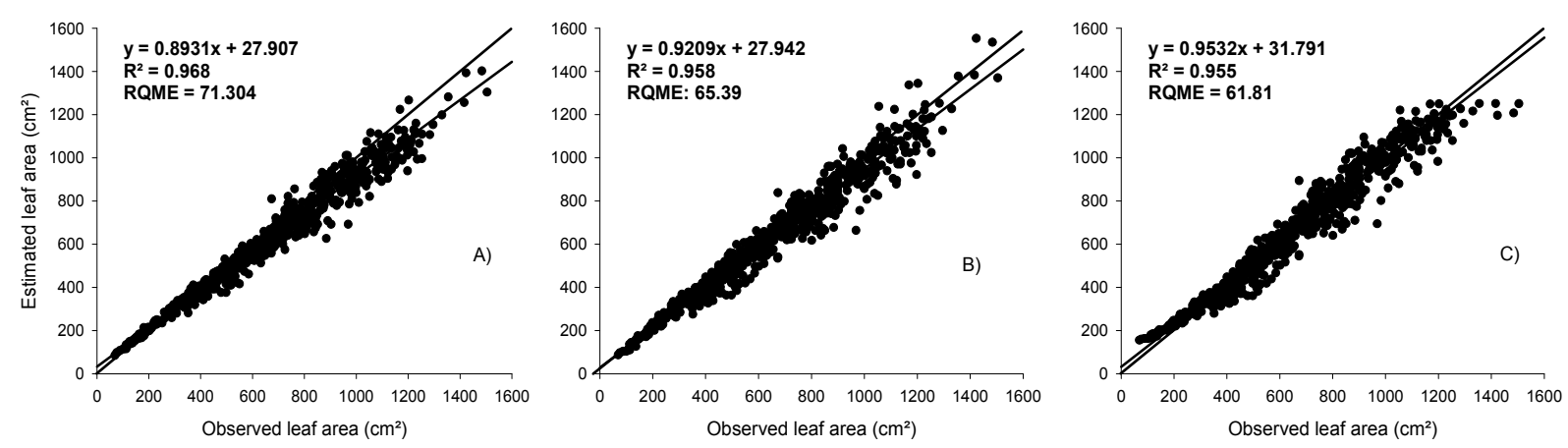

Figure 2. Linear model test (A) using as input variable the product of linear measurement length and width of tobacco, power (B) and quadratic (C) sheets, using the linear measurement of squared width multiplying by length

Models that use only one of the dimensions of the leaves are preferable, as there is a $50 \%$ reduction in the number of linear dimension measurements to be performed in the field. In the case of Tobacco, model 7 that uses only the width of the sheet could be indicated in cases that a lower accuracy is required in the estimation of the leaf area. This model can be widely used by companies working with tobacco to estimate the area of each leaf and possible damage caused by hail or pests.

\section{Conclusion}

Measurements of the leaf area of tobacco Nicotiana tabacum L. can be estimated from potential, linear and quadratic equations with good precision.

Models using linear squared width measurements multiplied by leaf limbo length $\left(\mathrm{L}^{2} \mathrm{C}\right)$ satisfactorily estimate the leaf area of tobacco. The use of this input variable in the quadratic model $\left(\mathrm{AF}=-0.00000024 \cdot\left(\mathrm{L}^{2} \mathrm{C}\right)^{2}+0.1299\right.$ $+133.43)$ and power $\left(\mathrm{AF}=1.6897 \cdot\left(\mathrm{L}^{2} \mathrm{C}\right) \cdot 0.5974\right)$ resulted in the best estimates of the leaf area. 


\section{References}

Busato, C., Fontes, P. C. R., Braun, H., \& Busato, C. C. M. (2010). Estimativa da área foliar da batateira, cultivar Atlantic, utilizando dimensões lineares. Revista Ciência Agronômica, 41(4), 702-708. https://doi.org/ 10.1590/S1806-66902010000400026

Candido, W. S., Coelho, M. F. B., Maia, S. S. S., Cunha, C. S. M., \& Silva, R. C. P. (2013). Modelo para estimar a área foliar de Combretum leprosum Mart. Acta Agronómica, Palmira, 62(1), 37-41.

Coelho Filho, M. A., Villa-Nova, N. A., Angelocci, L. R., Marin, F. R., \& Righi, C. A. (2012). Método para estimativa do IAF de árvores isoladas ou de plantações com dossel fechado. Revista Brasileira de Engenharia Agrícola e Ambiental, Campina Grande, 16(5), 529-538. https://doi.org/10.1590/S1415-436620 12000500009

EMBRAPA (Empresa Brasileira de Pesquisa Agropecuária). (2006). Sistema Brasileiro de Classificação de Solos (2nd ed., p. 306). Centro Nacional de Pesquisa de Solos, Rio de Janeiro.

Favarin, J. L., Dourado, N. D., García, A. G., Nova, N. A. V., \& Favarin, M. G. G. V. (2002). Equações para a estimativa do índice de área foliar do cafeeiro. Pesquisa Agropecuária Brasileira, 37(6), 769-73. https://doi.org/10.1590/S0100-204X2002000600005

Guerrero, R. C. (1995). El cultivo del tabaco (1st ed.). San José-Costa Rica: Editorial Universidad Estatal a Distância.

Guimarães, M. J. M., Coelho Filho, M. A., Junior, F. A. G., Silva, M. A. M., Alves, C. V. O., \& Lopes, I. (2019). Modelos matemáticos para a estimativa da área foliar de mandioca. Revista Amazonian Journal, 62. https://doi.org/10.22491/rca.2019.3015

Hannickel, A., Silva, M. H. P., Barros, H. L., \& Albuquerque, M. P. (2012). ImageJ como ferramenta para medida da área de partículas de magnetita em três escalas nanométricas. Instituto Militar de Engenharia (IME), Rio de Janeiro.

Heldwein, A. B., Buriol, G. A., \& Streck, N. A. (2009). O Clima de Santa Maria. Revista Ciência Ambiente, 38, 43-58.

Hinnah, D. H., Heldwein, A. B., Maldaner, I. C., Loose, L. H., Lucas, D. D. P., \& Bortoluzzi, M. P. (2014). Estimation of eggplant leaf area from leaf. Bragantia, 73, 213-218. https://doi.org/10.1590/1678-4499.0083

Janssen, P. H. M., \& Heuberger, P. S. C. (1995). Calibration of process-oriented models. Ecological Modelling, 83, 55-56. https://doi.org/10.1016/0304-3800(95)00084-9

Lima, R. T., Souza, P. J. O. P., Rodrigues, J. C., \& Lima, M. J. A. (2012). Modelos para estimativa da área foliar da mangueira utilizando medidas lineares. Revista Brasileira de Fruticultura, Jaboticabal, 34(4), 974-980. https://doi.org/10.1590/S0100-29452012000400003

Malagi, G., Citadin, I., Scariot, S., \& Reis, L. (2010). Método não destrutivo para determinação da área foliar da videira, cultivar BRS-Violeta. Revista Brasileira de Fruticultura, 32, 1250-1254. https://doi.org/10.1590/ S0100-29452011005000005

Maldaner, I. C., Heldwein, A. B., Loose, L. H., Lucas, D. D. P., Guse, F. I., \& Bortoluzzi, M. P. (2009). Modelos de determinação não destrutiva da área foliar em girassol. Ciência Rural, 39, 1356-1361. https://doi.org/ 10.1590/S0103-84782009000500008

Peixoto, C. P., Cruz, T. V., \& Peixoto, M. F. S. P. (2011). Análise quantitativa do crescimento de plantas: Conceitos e Prática. Enciclopédia Biosfera, 7, 51-76.

Peksen, E. (2007). Non-destructive leaf area estimation model for faba bean (Vicia faba L.). Scientia Horticulturae, 113, 322-328. https://doi.org/10.1016/j.scienta.2007.04.003

Posse, R. P., Sousa, E. F., Bernardo, S., Pereira, M. G., \& Gottardo, R. D. (2009). Total leaf area of papaya trees estimated by a non destructive method. Scientia Agricola, São Paulo, 66(4), 462-466. https://doi.org/ 10.1590/S0103-90162009000400005

Rasband, W. (2018). ImageJ Documentation, 2011. Retrieved from http://www.rsb.info.nih.gov

SBCS (Sociedade Brasileira de Ciência do Solo). (2016). Manual de calagem e adubação para os estados do Rio Grande do Sul e Santa Catarina. Comissão de Química e Fertilidade do Solo-RS-SC.

Schmildt, E. R., Amaral, J. A. T., Schmildt, O., \& Santos, J. S. (2014). Análise comparativa de equações para estimativa da área foliar em cafeeiros. Coffee Science, 9(2), 155-167. 
Schmildt, E. R., Trevisan, E., Belique, M., \& Schmildt, O. (2017). Modelos alométricos para determinação da área foliar de cacaueiro 'PH-16' em sombreamento e pleno sol.RevistaAgro@mbiente On-line, Roraima, 11(1), 47-55. https://doi.org/10.18227/1982-8470ragro.v11i1.3938

Silva, S. F., Cabanez, P. A., Mendonça, R. F., Pereira, L. R., \& Amaral, J. A. T. (2015). Modelos alométricos para estimativa da área foliar de mangueira pelo método não destrutivo. Revista Agro@mbiente On-line, Roraima, 9(1), 86-90. https://doi.org/10.5327/Z1982-8470201500012134

SINDITABACO (Sindicato Interestadual da Indústria do Tabaco). (2017). Estatísticas e Infográficos. Retrieved from http://sinditabaco.com.br

Taiz, L., \& Zeiger, E. (2013). Fisiologia vegetal (5th ed., p. 820). Porto Alegre: Artmed.

Tartaglia, F. L., Righi, E. Z., Rocha, L., Loose, L. H., Maldane, R. I. C., \& Heldwein, A. B. (2016). Non-destructive models for leaf area determination in canola. Revista Brasileira de Engenharia Agrícola e Ambiental, Campina Grande, 20(6), 551-556. https://doi.org/10.1590/1807-1929/agriambi.v20n6p551-556

Toebe, M., Cargnelutti Filho, A., Burin, C., Fick, A. L., Neu, I. M. M., Casarotto, G., \& Alves, B. M. (2012) Modelos para a estimação da área foliar de feijão de porco por dimensões foliares. Bragantia, 71, 37-41. https://doi.org/10.1590/S0006-87052012005000010

\section{Copyrights}

Copyright for this article is retained by the author(s), with first publication rights granted to the journal.

This is an open-access article distributed under the terms and conditions of the Creative Commons Attribution license (http://creativecommons.org/licenses/by/4.0/). 